\title{
Ossification of the superior transverse ligament in a South African scapula: a factor to be considered in the diagnosis of suprascapular nerve entrapment
}

\author{
AZU, O. ${ }^{1}$, OFUSORI, D. A. ${ }^{1,2,3 *}$, NAIDU, E. C. ${ }^{1}$ and NAIDU, J. S. ${ }^{1}$ \\ ${ }^{1}$ Discipline of Clinical Anatomy, Nelson R. Mandela School of Medicine, University of KwaZulu-Natal, \\ Durban, South Africa \\ ${ }^{2}$ Department of Anatomy and Cell Biology, Faculty of Basic Medical Sciences, Obafemi Awolowo University, \\ Ile-Ife, Osun State, Nigeria \\ ${ }^{3}$ Optics and Imaging Centre, School of Laboratory Medicine \& Medical Sciences, University of KwaZulu-Natal, \\ Durban, South Africa \\ *E-mail: davidofus234@yahoo.com
}

\begin{abstract}
Introduction: Ossification of the superior transverse scapular ligament is one of the factors considered in the classification of the suprascapular notch based on shape. Variation in morphology of the superior transverse scapular ligament is always considered a critical factor in the diagnosis of suprascapular nerve entrapment syndrome. Case Report: This study reports the complete ossification of the superior transverse scapular ligament in a South African scapula and a note on its clinical anatomy. Conclusion: This anatomical knowledge is of extreme clinical relevance to surgeons in relation to various syndromes associated with the shoulder region in the South African population.
\end{abstract}

Keywords: suprascapular notch, ossification, clinical anatomy.

\section{Introduction}

The suprascapular notch (SSN) is adjacent to the coracoid process on the superior border of the scapula (OFUSORI, UDE, OKWUONU et al., 2008). The superior transverse scapular ligament passes above this notch and converts it into a foramen. Within this foramen is the suprascapular nerve accompanied by its associated vein. The corresponding artery runs over the ligament. The suprascapular nerve is very important because it provides motor branches that supply the supraspinatus, infraspinatus and sensory branches to the rotator cuff muscles. In addition, it supplies the ligamentous structures of the shoulder and acromioclavicular joint (OFUSORI, UDE, OKWUONU et al., 2008). This region is the most common location of suprascapular nerve injury and compression (RENGACHARY, BURR, LUCAS et al., 1979; ZEHETGRUBER, NOSKE, LANG et al., 2002). Variations in the morphology of SSN have been documented (NATSIS, TOTLIS, TSIKARAS et al., 2007; BAYRAMOLU, DEMIRYÜREK, TÜCCAR et al., 2003) and the morphology of superior transverse scapular ligament was considered a critical factor in the clinical manifestation/consideration for anatomical variations. There is dearth of literature reporting a description of complete ossification of the superior transverse scapular ligament in South Africans. Hence, this case report describes complete ossification of the superior transverse scapular ligament in a South African scapula.

\section{Case Report}

During routine bone extraction for osteological study at the Discipline of Clinical Anatomy, Nelson R Mandela School of Medicine, Durban, South Africa, it was observed that one of the left scapula had a complete ossification of the superior transverse scapular ligament (Figures 1 and 2). The length of the ligament was $12.7 \mathrm{~mm}$; the width was $2.5 \mathrm{~mm}$ and the thickness was $4.7 \mathrm{~mm}$. The internal diameter was $7.3 \mathrm{~mm}$. The scapula presented features of a normal scapula. The costal surface was concave while the posterior surface was convex with the spine of the scapula dividing it into supraspinous and infraspinous fossae. The scapula was also characterized with superior, lateral and medial borders.

The superior border of the scapular is somewhat horizontal and becomes continuous with the ossified superior transverse scapular ligament as the latter passed over suprascapular notch thus, converting it into a suprascapular foramen (Figure 2).

\section{Discussion}

The morphology of the superior transverse scapular ligament (STSL) in relation with the suprascapular notch is considered anomalous and an important factor to be considered in the etiology of suprascapular nerve entrapment (HARRIS, VU, SONNABEND et al., 2001). Osuagwu, Imosemi and Shokunbi (2005) reported that ossification of superior transverse scapular ligament is rare in humans. In their study, complete ossification of the superior transverse scapular ligament was reported in a Nigerian male adult. Other studies such as Das, Suri and Kapur (2007) and Mohd (2006) reported on clinical implications of complete ossification of superior transverse scapular ligament. It should be noted that ossification of the superior transverse scapular ligament often compresses the suprascapular nerve thus resulting in relative weakness of infraspinatus muscle (DAS, SURI and KAPUR, 2007). Additionally, there may be associated pain in the shoulder region coupled with atrophy, abduction and weakness in external rotation of the 


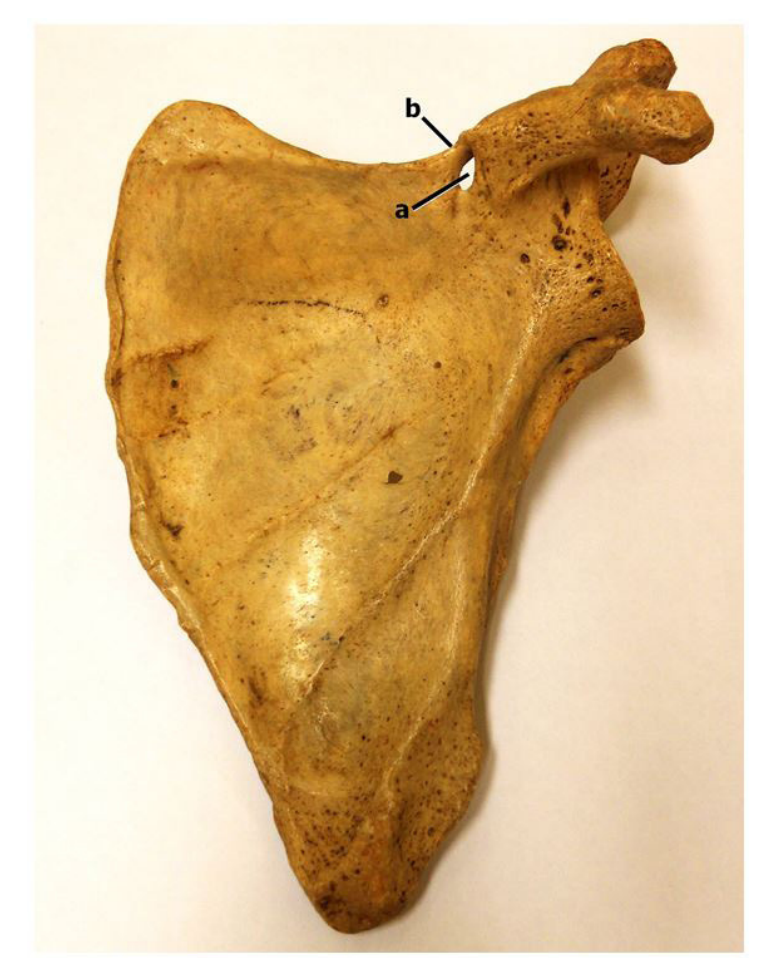

Figure 1. Showing the anterior view of a left scapular. Note the suprascapular notch (a) converted into a foramen by the superior transverse scapular ligament (b).

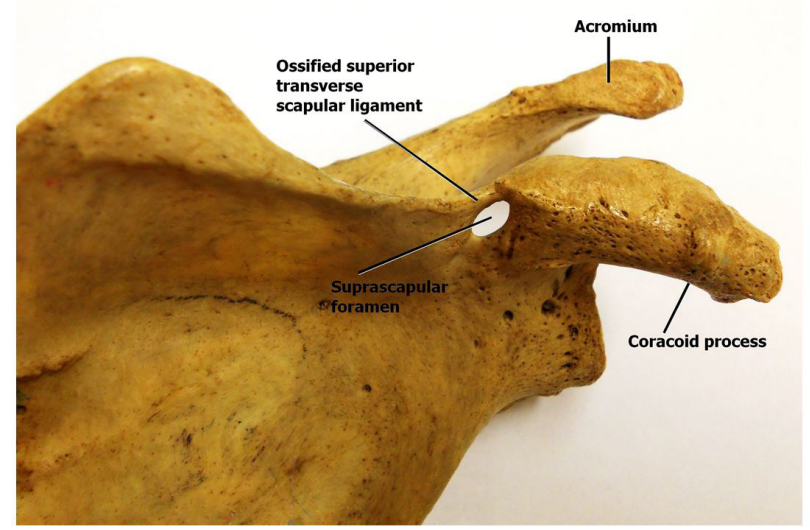

Figure 2. Showing the anterior (superolateral aspect) view of a left scapular.

supraspinatus muscle (SILVA, ABIDU-FIGUEIREDO, FERNANDES et al., 2007). The suprascapular notch is not the only site of possible compression of the suprascapular nerve; other site such as the base of the spine of the scapula is also a reference point in clinical diagnosis. Radiological reporting has been effective in identifying the sites of suprascapular nerve entrapment (DAS, SURI and KAPUR, 2007). In this study, it has been shown that complete ossification of the STSL can occur in a South African population similar to the report of Silva, Abidu-Figueiredo, Fernandes et al. (2007) in a Brazilian population. This report is yet to be documented before now in South African population.
This anatomical knowledge is of extreme clinical relevance to surgeons in relation to various syndromes associated with the shoulder region in the South African population. Again, the anatomical curiosity should be borne in mind by clinical anatomists as well as students approaching this region for various manipulations.

\section{References}

BAYRAMOLU, A., DEMIRYÜREK, D., TÜCCAR, E., ERBIL, M., ALDUR, MM. and TETIK, O. Variations in anatomy at the suprascapular notch possibly causing suprascapular nerve entrapment: an anatomical study. Knee Surgery, Sports Traumatology, Arthroscopy, 2003, vol. 11, n. 6, p. 393-398. PMid:12830371. http://dx.doi. org/10.1007/s00167-003-0378-3.

DAS, S., SURI, R. and KAPUR, V. Ossification of superior transverse scapular ligament and its clinical implications. Sultan Qaboos University Medical Journal, 2007, vol. 7, n. 2, p. 157-160. PMid:21748099.

HARRIS, RI., VU, DH., SONNABEND, DH., GOLDBERG, JA. and WALSH, WR. Anatomic variance of the coracoclavicular ligaments. Journal of Shoulder and Elbow Surgery, 2001, vol. 10, n. 6, p. 585-588. PMid:11743540. http://dx.doi.org/10.1067/mse.2001.118480.

MOHD, AK. Complete ossification of the superior transverse scapular ligament in an Indian male adult. International Journal of Morphology, 2006, vol. 24, p. 195-196.

NATSIS, K., TOTLIS, T., TSIKARAS, P., APPELL, HJ., SKANDALAKIS, P. and KOEBKE, J. Proposal for classification of the suprascapular notch: a study on 423 dried scapulas. Clinical Anatomy (New York, N.Y.), 2007, vol. 20, n. 2, p. 135-139. PMid:16838269. http:// dx.doi.org/10.1002/ca.20318.

OFUSORI, DA., UDE, RA., OKWUONU, CU. and ADESANYA, OA. Complete absence of the suprascapular notch in a Nigerian scapula: a possible cause of suprascapular nerve entrapment. International Journal of Shoulder Surgery, 2008, vol. 2, n. 4, p. 85-86. PMid:20300326. http://dx.doi.org/10.4103/0973-6042.44146.

OSUAGWU, FC., IMOSEMI, IO. and SHOKUNBI, MT. Complete ossification of the superior transverse scapular ligament in a Nigerian male adult. International Journal of Morphology, 2005, vol. 23, n. 2, p. 121-122. http://dx.doi.org/10.4067/S0717-95022005000200004.

RENGACHARY, SS., BURR, D., LUCAS, S., HASSANEIN, KM., MOHN, MP. and MATZKE, H. Suprascapular entrapment neuropathy: a clinical, anatomical, and comparative study. Part 1: clinical study. Neurosurgery, 1979, vol. 5, n. 4, p. 441-446. PMid:534047. http:// dx.doi.org/10.1227/00006123-197910000-00006.

SILVA, JG., ABIDU-FIGUEIREDO, M., FERNANDES, RMP., AURELIANO-RAFAEL, F., SGROTT, EA., SILVA, SF. and BABINSKI, MA. High incidence of complete ossification of the superior transverse scapular ligament in Brazilians and its clinical implications. International Journal of Morphology, 2007, vol. 25, n. 4, p. 855-859. http://dx.doi.org/10.4067/S0717-95022007000400028.

ZEHETGRUBER, H., NOSKE, H., LANG, T. and WURNIG, C. Suprascapular nerve entrapment: a meta-analysis. International Orthopaedics, 2002, vol. 26, n. 6, p. 339-343. PMid:12466865. http://dx.doi.org/10.1007/s00264-002-0392-y.

Received April 22, 2015 Accepted October 13, 2016 